\title{
Aspek Mikrobiologis serta Sensori (Rasa, Warna, Tekstur, Aroma) pada Dua Bentuk Penyajian Keju yang Berbeda
}

\author{
Microbiologist Aspects and Sensory (Flavor, Color, Texture, Aroma) In Two Different Presentation \\ Soft Cheese
}

\author{
J. K. Negara, A. K. Sio, Rifkhan, M. Arifin, A. Y. Oktaviana, R. R. S. Wihansah, M. Yusuf \\ Mahasiswa Sekolah Pascasarjana, Departemen Ilmu Produksi dan Teknologi Peternakan \\ Fakultas Peternakan, Institut Pertanian Bogor \\ Email : thtseru@gmail.com
}

\begin{abstract}
This study was conducted to determine the contamination of microorganisms, $\mathrm{pH}$, water activity $\left(a_{w}\right)$, as well as sensory tests (color, aroma, flavor, and texture) with the presentation of different cheeses. This research was conducted in an Laboratorium Terpadu and Laboratorium Phatogen, Teknologi Hasil Ternak, Program Study Ilmu Produksi dan Teknologi Peternakan, Fakultas Peternakan, Bogor Agricultural University. Data from the observations in doing calculations using t-test mathematical model of this design is $t=\frac{x-\mu_{0} x-\mu_{0}}{S \sqrt{n} S \sqrt{n}}$ with 2 times each replicate. The variables measured were the value of Total Plate Count ( $\left(\mathrm{P}^{\sqrt{2}}\right)$, , Potato Dextrote Agar (PDA), pH, $\mathbf{a}_{w}$, and a sensory test. Data were analyzed using t-test model. The results of the analysis of the t-test $(\alpha=5 \%)$ of cheddar cheese block and cheddar cheese slice stem not give significant differences $(P>0,05)$ on the TPC and PDA yeasts or fungi. t-test $(\alpha=5 \%)$ to $\mathrm{pH}$ and $\mathrm{a}_{\mathrm{w}}$ on each individual cheese does not give significant differences $(\mathrm{P}>$ $0,05)$. From the results of sensory analysis on the color of the cheese is seen that the panelists really liked the cheese sticks. Rate on cheese stem higher with the average value of which is $\mathbf{4}$ compared with cheddar cheese shaped slice which has an average value is 3,7 . as well as on the assessment of texture and flavor, the rod-shaped cheddar cheese has a value - average higher than shaped slice of cheddar cheese. while the aroma cheddar cheese slice has a higher average value than the rod-shaped cheddar cheese. However this is seen not provide a significant difference due to differences in cheese and cheese slice stem relatively small. On the results of the analysis (t-test) showed that the difference in assessment of color, texture, aroma and taste of the cheese slice and cheese stems not significant or not significant. This is most likely because of the cheese slice and rods produced by the company that produced simultaneously.
\end{abstract}

Keywords :Cheddar cheese, microbiologys aspect, sensory

\section{PENDAHULUAN}

Keju adalah sebuah makanan yang dihasilkan zat-zat padat dalam susu melalui proses pengentalan atau koagulasi. Proses pengentalan ini dilakukan dengan bantuan bakteri atau enzim tertentu yang disebut rennet. Hasil dari proses tersebut nantinya akan dikeringkan, diproses, dan diawetkan dengan berbagai macam cara. Dari sebuah susu dapat diproduksi berbagai variasi produk keju. Produkproduk keju bervariasi ditentukan dari tipe susu, metode pengentalan, temperatur, metode pemotongan, pengeringan, pemanasan,juga proses pematangan keju dan pengawetan.

Keju memiliki kandungan protein $19,4 \%$, lemak 21,6\%, dan karbohidrat 2,20\%. Selain itu, keju juga memiliki kandungan air yang tinggi, yaitu 54,1\%. Hal ini menjadikan keju sebagai bahan pangan yang sangat rawan terhadap pertumbuhan mikroorganisme. Pertumbuhanmikroorganisme di dalam keju akan mengakibatkan kerusakan pada keju tersebut.(HUT 1993).

Oleh Karena itu perbedaan bentuk produk keju yang didukung dengan cara pengemasan dan penyimpanan sering juga menentukan kualitas dari produk keju. Ketahanan kejuakan berbeda-beda tergantung jenis bahan dan kandungan gizi didalamnya dan perlakuan yang kita berikan terhadap bahan pangan tersebut, sehingga kami melakukan pengamatan terhadap 2 bentuk keju yang berbedaya itu berbentuk batang dan berbentuk slice. Tujuan dari penelitian ini adalah untuk mengetahui cemaran mikroorganisme, nilai $\mathrm{pH}$, water activity $\left(\mathrm{a}_{\mathrm{w}}\right)$, serta uji sensori (warna, aroma, rasa, dantekstur).

\section{MATERI DAN METODE}

Penelitian ini dilakukan pada laboratorium terpadu dan laboratorium patogen, Teknologi Hasil Ternak, Program Studi Ilmu Produksi dan Teknologi Peternakan, Fakultas peternakan Institut Pertanian Bogor pada tanggal 27 0ktober sampai dengan 24 November 2016.

Alat-alat yang digunakan dalam percobaan ini adalah tabung reaksi steril, cawan petri steril, handscol, 
masker, lampu bunsen,Laminar Air Flow Cabinet, Mikropipet,pH Meter, a $\mathrm{a}_{\mathrm{w}}$ Meter, Bluetip, Tabung Reaksi, Rak Tabung Reaksi, Spatula,Neraca Analitik, Erlenmeyer, Autoclafe, Bulpoin, Mangkuk, Korek, Tissu dan Voertex.

Bahan bahan yang digunakan dalam percobaan ini adalah sampel keju yang berbentuk slice dan batang, PCA, PDA, alkohol 70 dan $90 \%$, spritus, $\mathrm{NaCl} \quad$ 0,9\% dan aquades. Metode yang dipakai dalam penelitian ini adalah dengan Metode Bacteriologi Analytical Manual (2001).

Total Plate Count dilakukan adalah suatu cara menumbuhkan mikroorganisme pada media agar. Hal ini dilakukan dengan cara Sampel keju timbang 25 gram secara aseptik dan dilakukan homogenesasi menggunakan blender/dimixing pada sampel yang telah ditimbang dengan ditambahkan 225 larutan buffered peptone water (BPW) sehingga diperoleh pengenceran $10^{-1}$. Sampelkejukemudian dipindahkan sebanyak $1 \mathrm{ml}$ campuran secara aseptik kedalam tabung reaksi yang berisi $9 \mathrm{ml}$ larutan buffered peptone water (BPW) sehingga diperoleh pengenceran 102. Ulangi prosedur ini sampai diperoleh pengenceran $10^{-3}$, $10^{-4}, 10^{-5}$

Sampel yang sudah melalui pengenceran pindahkan sebanyak $1 \mathrm{ml}$ masing-masing pengenceran $10^{-3}, 10^{-4}$, dan $10^{-5}$ secara duplo dan secara aseptik kedalam cawan petri yang telah disterilkan sebelumnya kemudian ditambahkan sebanyak 15-20 ml larutan media plate count agar (PCA) bersuhu $40^{\circ} \mathrm{C}$ kedalam cawan petri dan biarkan hingga larutan mengeras.

Setelah media agar mengeras kemudian diinkubasi kedalam inkubator pada suhu $35+1^{\circ} \mathrm{C}$ selama $24+3$ jam dan setelah itu menghitung koloni yang terbentuk. Potato Dextrose Agar adalah salah satu media kultur yang paling umum digunakan karena formulasinya yang sedehana dan merupakan media terbaik karena kemampuannya dalam mendukung pertumbuhan pada berbagai kapang dan khamir (Saha et al. 2008).

Untuk membuat media PDA terlebih dahulu Sampel keju timbang 25 gram secara aseptik yang sebelumnya sampel dihomogenesasi menggunakan blender/dimixing pada sampel yang telah ditimbang dengan ditambahkan 225 larutan buffered peptone water (BPW) sehingga diperoleh pengenceran $10^{-1}$. Kemudian sampel keju dipindahkan sebanyak $1 \mathrm{ml}$ masing masing pengenceran $10^{-1}, 10^{-2}$, dan $10^{-3}$ secara duplo dan secara aseptik kedalam tabung reaksi yang telah berisi larutan buffered peptone water (BPW).

Kemudian pindahkan sebanyak $1 \mathrm{ml}$ masing masing pengenceran $10^{-1}, 10^{-2}$, dan $10^{-3}$ kedalam cawan petri dan tambahkan sebanyak 15-20 ml larutan media Potato Dextrote Agar (PDA) bersuhu $40^{\circ} \mathrm{C}$ kedalam cawan petri dan biarkan hingga larutan mengeras. Inkubasi cawan petri yang telah diberi media kedalam inkubator pada suhu 35+ $1^{\circ} \mathrm{C}$ selama $48+3$ jam dan setelah itu menghitung koloni yang terbentuk.

$\mathrm{pH}$ adalah konsentrasi hidrogen ion yang bersifat asam dan basa, nilai normal $\mathrm{pH}$ yaitu 7 dan jika dibawa tujuh maka bersifat asam dan diatas tujuh maka bersifat basa. (Buck 2002)

Menganalisis $\mathrm{pH}$ keju dalam penelitian ini langkahlangkah dilakukan adalah Alat $\mathrm{pH}$ meter dihidupkan 20-30 menit sebelum pengukuran kemudian tombol pengatur suhu larutan yang akan di ukur $\mathrm{pH}$-nya disesuaikan. $\mathrm{pH}$ meter kemudian dikalibrasi dengan cara elektroda $\mathrm{pH}$ meter tersebut dimasukan ke dalam larutan penyangga baku (Standar Buffer) pH 7, dan tunggu sampai tulisan "ready" tertera pada $\mathrm{pH}$ meter tersebut.

Sampel keju batang disiapkan dengan cara di potong berbentuk kotak dan keju slice di remas berbentuk gumparan Elektroda $\mathrm{pH}$ meter kemudian dicuci dengan aquades dan dikeringkan dengan menggunakan tissue.Kemudian elektroda di tusukan kedalam sampel keju dan menunggu sampai nilai $\mathrm{pH}$ pada $\mathrm{pH}$ meter tersebut berhenti.Angka yang di dapat kemudian dicatat.

Activity Water $\left(a_{w}\right)$ adalah banyaknya jumlah air dalam bahan pangan yang digunakan mikroorganisme untuk bertumbuh dan berkembangbiak. Untuk menganalisis $\mathrm{a}_{\mathrm{w}}$ pada sampel keju langkah-langkah yang diilakukan adalah $\mathrm{a}_{\mathrm{w}}$ meter dihidupkan kemudian dikalibrasikan dengan memasukan cairan $\mathrm{NaCl}_{2} \cdot \mathrm{H}_{2} \mathrm{O}$ teknis kedalam tempat sampel Kemudian alat $\mathrm{a}_{\mathrm{w}}$ ditutup dibiarkan selama 3 menit sampai angka pada skala pembacaan $a_{w}$ menjadi 0,9 $\mathrm{a}_{\mathrm{w}}$ meter kemudian dibuka dan tempat sampel dibersikan. KemudianSampel keju dimasukan kemudian ditunggu 5 -10 menitdanSetelah 5 menit, skala $\mathrm{a}_{\mathrm{w}}$ dibaca dan dicatat. Lalu perhatikan skala temperatur untuk faktor koreksinya.

Pengujian sensoris dilakukan pada laboratorium organoleptik dan melibatkan mahasiswa IPB sebanyak 30 orang sebagai panelis. Sebelum melakukan uji sensoris terlebih dahulu mempersiapkan kusioner untuk digunakan panelis untuk memberikan penilaian pada produk keju tersebut. Panelis diberikan keju slice 3 gr dan keju batang 3 gram untuk dilakukan pengamatan.

Data hasil pengamatan di lakukan perhitungan dengan menggunakan uji t-test Model matematik dari rancangan ini adalah sebagai berikut.

$\mathbf{t}=\frac{X-\mu_{0} X-\mu_{0}}{S / \sqrt{n} S / \sqrt{n}}$

Dimana :

$\mathrm{t} \quad=\mathrm{t}$ hitung

$\mathrm{X}=$ rata - rata sampel

$\mu_{0} \mu_{0}=$ rata - rata spesifik atau rata - rata tertentu (yang menjadi pebanding)

$\mathrm{S}=$ standar deviasi sampel

$\mathrm{n} \quad$ = jumlah sampel

\section{HASIL DAN PEMBAHASAN}

\section{Mikroorganisme Keju Cheddar Dengan Merk yang Sama}

Jenis cemaran mikroba yang terdapat pada makanan dapat meliputi berbagai mikroorganisme seperti bakteri, kapang dan khamir. Cemaran mikroorganisme tersebut dapat dari cemaran bahan baku, pada saat proses pembuatan produk, pada saat pengepakan dan lama penyimpanan.

Indikator cemaran mikroorganisme ini adalah golongan atau spesies bakteri yang kehadirannya dalam makanan dalam jumlah diatas batas (limit) tertentu, merupakan pertanda bahwa makanan telah terpapar dengan kondisi-kondisi yang memungkinkan berkembang biaknya 
Tabel 1 Kualitas mikrobiologi keju cheddar

\begin{tabular}{lcc}
\hline Mikroorganisme & $\begin{array}{c}\text { Keju cheddar } \\
\text { Batang log cfu/g }\end{array}$ & $\begin{array}{c}\text { Keju cheddar Slice } \\
\log \mathrm{cfu} / \mathrm{g}\end{array}$ \\
\hline TPC & $3,236 \pm 0,445$ & $3,590 \pm 1,686$ \\
Kapang, Khamir & $4,530 \pm 0,762$ & $2,562 \pm 0,312$ \\
\hline
\end{tabular}

Perbandingan secara horizontal pada keju cheddar batang dan keju cheddarslice tidak berbedan yata terhadap nilai TPC dan Kapang, Khamir

mikroba patogen. Mikroba indikator digunakan untuk menilai keamanan dan mutu mikrobiologi makanan.

Uji mutu mikroorganisme salah satunya adalah TPC (Total Plate Count) salah satu metode untuk menghitung suatu koloni mikroba yang terdapat pada suatu cemaran dari suatu produk yang ditumbuhkan pada media agar (SNI 2897:2008). Dalam uji TPC pada keju cheddarbatang yaitu dengan rata-rata $3,903 \mathrm{cfu} / \mathrm{g}$ dan pada keju cheddar slice dengan rata-rata 3,656 cfu/g sedangkan pada penelitianVarga László (2007) menyatakan bahwa standar TPC keju cheddar secara umum adalah $5,0 \times 10^{4} \mathrm{cfu} / \mathrm{g}$ sehingga keju cheddar yang digunakan adalah layak untuk dikomersilkan berikut adalah data hasil pengujian mikroorganisme.

Berdasarkan tabel diatas menunjukkan Hasil analisis uji t $(\alpha=5 \%)$ keju cheddar batang dan keju cheddar slice tidak memberikan perbedaan yang nyata $(\mathrm{P}>0,05)$ terhadap TPC dan kapang khamir masing-masing keju cheddar. Data yang disajikan menunjukkan bahwa cemaran mikroorganisme pada masing-masing keju cheddar batang adalah 3,236 log cfu/g dan 3,390 log cfu/g pada keju cheddar slice yang berarti terdapat $10^{3} \mathrm{cfu} / \mathrm{g}$ cemaran mikroorganisme TPC dan kapang khamir pada keju cheddar cheddarbatang, begitupun pada keju cheddar slice.

Kondisi tersebut menunjukkan persamaan kualitas produk dengan merek yang sama tetapi berbeda dalam penyajian dari segi cemaran mikrooganisme TPC pada keju cheddar batang dan slice, hal ini terjadi karena bahan dan perlakuan pembuatan keju serta treatmen yang diberikan kemungkinan sama hanya saja berbeda dalam penyajian dan bentuk kemasannya yang berbeda. Kemasan keju cheddar merupakan kemasan retort pouch atau kemasan laminasi alumunium foil, yaitu kombinasi antara alumunium foil dengan beberapa jenis plastik sebagai kemasan primer dan kemasan keju cheddar slice merupakan kemasan plastik yang isi per satu kemasan adalah 7 slice keju cheddar dengan dilapisi kemasan plastik yang tertutup rapat/kedap udara pada masing-masing slice.

Penggunaan plastik dapat mencegah kontaminasi terhadap berbagai mikroorganisme dan terjadinya oksidasi sedanngkan pada penggunaan alumunium foil dapat mencegah kontaminasi berbagai mikroorganisme dan mencegah terjadinya perubahan kualitas keju cheddar batang ini sejalan dengan Winarno et al. (1980) dalam Dardanella Derry (2007), penggunaan laminasi alumunium foil sangat baik untuk mengemas makanan karena makanan yang kontak dengan logam seperti alumunium foil dapat menghasilkan warna dan cita rasa yang tidak diinginkan pada makanan, selain itu pelapisan atau coating dapat mencegah terjadinya korosi pada logam (alumunium foil).
Adanya jenis pengawet nisin yang terdapat pada produk merupakan faktor utama dalam mencegah pencemaran mikroorganisme terutama kapang dan khamir. Rendahnya pertumbuhan kapang pada setiap keju cheddar batang maupun slice disebabkan oleh pengawet yang terdapat pada produk keju cheddar, yaitu asam sorbat, nisin, dan asam laktat. Penggunaan asam sorbat pada keju cheddar dimaksudkan untuk mencegah pertumbuhan kapang (Dardanella Derry 2007). Menurut Buckle et al. (1987) asam sorbat mempunyai aktivitas dengan spektrum yang lebar terhadap banyak khamir dan kapang, tetapi tidak seefektif terhadap bakteri, Lactobacilli, Staphylococci dan Clostridia tidak terhambat oleh sorbat. Untuk itu ditambahkan pengawet lain yaitu nisin yang digunakan sebagai antibiotik pada keju cheddar.

\section{Uji Fisik Keju cheddar}

Uji fisik merupakan bagian yang sangat penting untuk melihat kualitas dari suatu produk pada penelitian ini uji fisik yang dilakukan adalah pada $\mathrm{pH}$ dan $\mathrm{a}_{\mathrm{w}}$. Disajikan pada Tabel 2 .

Tabel 2 Uji fisik keju cheddar

\begin{tabular}{lll}
\hline & $\begin{array}{l}\text { Keju cheddar Batang } \\
\log / \mathrm{g}\end{array}$ & $\begin{array}{l}\text { Keju cheddar Slice } \\
\log / \mathrm{g}\end{array}$ \\
\hline $\mathrm{pH}$ & $5,3800 \pm 0,0900$ & $5,2000 \pm 0,1200$ \\
$\mathrm{aw}$ & $0,8835 \pm 0,0075$ & $0,8530 \pm 0,0340$ \\
\hline
\end{tabular}

Perbandingan secara horizontal pada keju cheddar batang dan keju cheddar slice tidak berbeda nyata terhadap nilai $\mathrm{pH}$ dan aw.

Pengukuran nilai $\mathrm{pH}$ perlu dilakukan untuk mengetahui tingkat keasaman/ kebasaan produk dan juga kaitannya dengan keamanan dan umur simpan produk tersebut.Nilai $\mathrm{pH}$ menjadi faktor penting untuk suatu produk makanan bila dihubungkan dengan kualitas produk.

Peranan air dalam suatu produk atau bahan pangan adalah dinyatakan sebagai kadar air dan aktivitas air. Aktivitas air $\left(\mathrm{a}_{\mathrm{w}}\right)$ adalah jumlah air bebas yang bisa termanfaatkan untuk pertumbuhan mikroorganisme (Winarno dan Jenie 1983 dalam Dardanella Derry 2007). Aktivitas air adalah air yang tidak terikat atau bebas dalam suatu sistem yang bisa menunjang reaksi biologis dan kimiawi. Air yang terkandung dalam produk atau bahan pangan, apabila terikat kuat dengan komponen bukan air akan lebih susah untuk digunakan dengan baik pada aktivitas mikrobiologis maupun aktivitas kimia dan hidrolitik (Syarief dan Khalid, 1992 dalam Dardanella Derry 2007). Aktivitas air adalah air yang tidak terikat ata ). sehinga perlu adanya pengecekan $\mathrm{a}_{\mathrm{w}}$, berikut adalah tabel yang menunjukkan nilai $\mathrm{pH}$ dan $\mathrm{a}_{\mathrm{w}}$ pada Tabel 2.

Berdasarkan tabel diatas menunjukkan Hasil analisis uji t ( $\alpha=5 \%$ ) keju cheddar batang dan keju cheddar slice tidak memberikan perbedaan yang nyata $(\mathrm{P}>0,05)$ terhadap $\mathrm{pH}$ dan $\mathrm{a}_{\mathrm{w}}$ pada masing-masing keju cheddar. Pada penelitian ini nilai $\mathrm{pH}$ yang ditunjukkan pada suatu keju cheddar dengan penyajian yang berbeda rata-rata adalah 5,38 pada keju cheddar batang dan 5,2 pada keju cheddar slice. Hal ini dimungkinkan bahwaadanya persamaan pada tanggal produksi dan lama penyimpanan yang sama sehingga tidak berbeda nyata. Semakin cepat daya beli dari 
konsumen maka keasaman yang terdapat pada keju akan semakin terjaga begitupun sebaliknya, ini sejalan dengan hasil penelitian oleh Dardanella Derry (2007) bahwa semakin lama penyimpanan keju cheddar maka $\mathrm{pH}$ akan berubah menjadi lebih basa atau kehilangan keasamannya dan nilai $\mathrm{pH}$ dapat berpengaruh terhadap rasa dari suatu produk makanan. Namun dalam penelitian ini perubahan $\mathrm{pH}$ masih cukup stabil dari masing-masing keju sehingga tidak memberikan pengaruh yang nyata.

Kisaran $\mathrm{a}_{\mathrm{w}}$ yang terdapat masing-masing penyajian adalah rata-arata 0,8 , ini kemungkinan nilai $a_{w}$ dapat dipengaruhi oleh mikroorganisme yang terdapat dalam keju, sehingga besar kecilnya nilai $\mathrm{a}_{\mathrm{w}}$ tergantung pada cemaran mikroorganisme yang masih dapat tumbuh dan berkembang pada $a_{w}$ tersebut. Pertumbuahan mikroorganisme tidak lepas dari hasil metabolis memikroorganisme yang dapat mempengaruhi nilai $\mathrm{a}_{\mathrm{w}}$.

Rata-rata pertmbuhankapang dan khamir pada keju cheddar penelitian ini adalah pada kisaran $10^{3} \mathrm{cfu} / \mathrm{g}$ yang membuktikan bahwa memang terdapat adanaya aktivitas kapang dan khamir pada masing-masing keju cheddar. Kapang dapat tumbuh dengan $\mathrm{a}_{\mathrm{w}}$ minimum sebesar 0,8 . Berbagai mikroorganisme mempunyai $a_{w}$ minimum agar dapat tumbuh dengan baik, misalnya bakteri dengan $\mathrm{a}_{\mathrm{w}}: 0,90$; khamir $\mathrm{a}_{\mathrm{w}}: 0,80-0,90$; kapang $\mathrm{a}_{\mathrm{w}}: 0,60-0,70$ (Winarno 1992 dalam Zulidar Juliana 2011).

\section{Uji Organoleptik}

Pengujian organoleptik adalah pengujian yang didasarkan pada proses penginderaan. Bagian organ tubuh yang berperan dalam penginderaan adalah mata, telinga, indera pencicip, indera pembau dan indera perabaan atau sentuhan. Kemampuan alat indera memberikan kesan atau tanggapan dapat dianalisis atau dibedakan berdasarkan jenis kesan. Luas daerah kesan adalah gambaran dari sebaran atau cakupan alat indera yang menerima rangsangan. Kemampuan memberikan kesan dapat dibedakan berdasarkan kemampuan alat indra memberikan reaksi atas rangsangan yang diterima. Kemampuan tersebut meliputi kemampuan mendeteksi (detection), mengenali (recognition), membedakan (discrimination), membandingkan (scalling) dan kemampuan menyatakan suka atau tidak suka (hedonik) (Saleh, 2004).

Untuk melaksanakan penelitian organoleptik diperlukan panel. Dalam penilaian mutu atau analisis siat - sifat sensori suatu komoditi, panel bertindak sebagai instrument atau alat. Panel ini terdiri dari orang atau kelompok yang bertugas menilai sifat atau mutu Komoditi berdasarkan kesan subjektif. Orang yang menjadi anggota panel disebut panelis.

Kriteria-kriteria tersebut sudah dapat dikaitkan untuk mewakili kualitas suatu bahan pangan, baik minuman maupun makanan. Selain itu, sistem ini sudah banyak dibakukan dan dijadikan sebagai alat bantu dalam laboratorium dan bidang lainnya. Namun, hasil yang didapat tidak $100 \%$ menjamin kebenaran, karena didalamnya hanya diperlihatkan perlakuan yang terbaik atau yang paling disenangi oleh para panelis. Atau kekurangannya adalah penilaian dapat bersifat subjektif. Karena itu uji organoleptik ini biasa disebut dengan uji hedonik.

Uji ini tidak akan memperlihatkan suatu produk yang disenangi oleh panelis karena dalam pengujiannya telah diacak. Oleh karenanya dibutuhkan suatu analisis data untuk menggabungkan berbagai penilaian yang telah didapat.

Keju adalah salah satu produk olahan yang berbahan dasar susu yang dikoagulasikan dengan menggunakan fermentasi bakteri asam laktat atau dengan memanfaatkan enzim rennet sehingga terjadi curd dan pemisahan serum susu. Hampir semua keju yang dipasarkan di Indonesia adalah keju keras, yaitu keju yang memerlukan tahap pematangan lebih lama sehingga biaya produksi lebih tinggi. Namun saat ini juga produk keju di indonesia memiliki berbagai macam bentuk diantaranya bentuk slice dan bentuk batang.

Pengujian organoleptik dilakukan untuk mengetahui tingkat kesukaan pada keju yang mempunyai perbedaan bentuk baik itu dilihat dari warna, tekstur, aroma dan rasa dengan skala mutu nya sangat tidak suka diberi skor (1), tidak suka diberi skor (2), netral diberi skor (3), suka diberi skor (4), dan sangat suka diberi skor (5) pada keju yang berbentuk slice dan batang.

\section{Warna}

Warna merupakan sensori pertama yang dapat dilihat langsung oleh panelis. penentuan mutu bahan makanan umumnya bergantung pada warna yang dimilikinya, warna yang tidak menyimpang dari warna yang seharusnya akan memberi kesan penilaian tersendiri oleh panelis. Data hasil perhitungan warna keju antara keju slice dan keju batang dapat dilihat pada Tabel 3 .

Dari hasil pengamatan uji organoleptik pada warna keju terlihat bahwa para panelis sangat menyukai pada keju batang. Pada keju batang lebih tinggi dengan rata rata nilai yaitu 4 dibandingkan dengan keju slice yang memiliki rata rata nilai yaitu 3,7. Namun hal ini terlihat tidak memberikan perbedaan yang signifikan dikarenakan perbedaan pada keju slice dan keju batang relative kecil.

Hasil analisis (uji-t) menunjukan bahwa perbedaan penilaian pada keju slice dan keju batang tidak signifikan. Perhitungan uji t (t-test) adalah - 1,16< dari 2,101 $\left(\mathrm{t}_{\text {tabel }}\right)$. Hal ini kemungkinan terjadi karena warna pada keju slice dan batang tidak telalu berbeda karena berasal dari satu produk.

\section{Tektur}

Tekstur berupa kelembutan serat keju yang diamati dengan indera peraba dikelompokkan menjadi 3 kategori yaitu tidak empuk, agak empuk dan empuk. Data hasil perhitungan uji organoleptik aroma keju antara keju slice dan keju batang dapat dilihat pada Tabel 3 .

Dari hasil pengamatan uji organoleptik pada tekstur keju terlihat bahwa para panelis sangat menyukai tekstur pada keju batang. Nilai tekstur pada keju batang lebih tinggi dengan rata rata yaitu 4,15 dibandingkan dengan tekstur keju slice yang memiliki rata rata nilai yaitu 3,7. Namun hal ini terlihat bahwa kedua keju tersebut tidak memberikan perbedaan yang signifikan dikarenakan perbedaan tekstur pada keju slice dan keju batang relative kecil.

Hasil analisis (uji-t) menunjukan bahwa perbedaan 
Tabel 3 Pengujian warna organoleptik pada keju slice dan keju batang

\begin{tabular}{llcc}
\hline Uji & Parameter & Keju Slice & Keju Batang \\
\hline Mutu Hedonik & Warna & 3,70 & 4,00 \\
& Tekstur & 3,70 & 4,15 \\
& Aroma & 4,15 & 4,05 \\
& Rasa & 4,25 & 4,55 \\
\hline
\end{tabular}

Rata-rata secara horizontal pada pengujian warna organoleptik keju cheddar batang dan keju cheddar slice

penilaian pada keju slice dan keju batang tidak signifikan atau tidak berbeda nyata. Perhitungan uji t (t-test) adalah 2,04< dari 2,101 $\left(\mathrm{t}_{\text {tabel }}\right)$. Hal ini kemungkinan terjadi karena tekstur pada keju slice dan batang tidak telalu berbeda karena berasal dari satu produk.

\section{Aroma}

Aroma adalah bau yang ditimbulkan oleh rangsangan kimia yang tercium oleh syaraf-syaraf olfaktori yang berada dalam rongga hidung, aroma pada keju dihasilkan oleh kerja bakteri asam laktat yang berperan untuk menimbulkan aroma dan asam. Data hasil perhitungan uji organoleptik aroma keju antara keju slice dan keju batang dapat dilihat pada Tabel 3.

Dari hasil pengamatan uji organoleptik pada aroma keju antara keju slice dan keju batang terlihat bahwa para panelis sangat menyukai aroma pada keju slice. Nilai ratarata aromar pada keju slice lebih tinggi dengan rata rata yaitu 4,15 dibandingkan dengan aroma pada keju batang yang memiliki rata rata nilai yaitu 4,05 . Namun hal ini terlihat bahwa kedua keju tersebut tidak memberikan perbedaan yang signifikan dikarenakan perbedaan aroma pada keju slice dan keju batang relative kecil.

Hasil analisis (uji-t) menunjukan bahwa perbedaan penilaian aroma pada keju slice dan keju batang tidak signifikan atau tidak berbeda nyata. Perhitungan uji t (t-test) adalah 0,37< dari 2,101 $\left(\mathrm{t}_{\text {tabel }}\right)$. Hal ini kemungkinan terjadi karena pada keju slice dan batang tidak telalu berbeda karena memiliki aroma yang sama dikarenakan berasal dari satu produk.

\section{Rasa}

Rasa adalah tingkat kesukaan dari keju yang diamati dengan indera perasa dikelompokkan menjadi 3 kategori yaitu kurang enak, enak dan sangat enak. Data hasil perhitungan uji organoleptik rasa keju antara keju slice dan keju batang dapat dilihat pada Tabel 3.

Dari hasil pengamatan uji organoleptik pada rasa keju antara keju slice dan keju batang terlihat bahwa para panelis sangat menyukai rasa pada keju batang. Nilai ratarata rasa keju pada keju batang lebih tinggi dengan rata rata yaitu 4,55 dibandingkan dengan rasa pada keju slice yang memiliki rata rata nilai yaitu 4,25 . Namun hal ini terlihat bahwa kedua keju tersebut tidak memberikan perbedaan yang signifikan dikarenakan perbedaan rasa pada keju slice dan keju batang relative kecil.

Hasil analisis (uji-t) menunjukan bahwa perbedaan penilaian rasa pada keju slice dan keju batang tidak signifikan atau tidak berbeda nyata. Perhitungan uji t (t-test) pada kedua keju tersebut adalah $-1,276<$ dari 2,101 ( $\left.\mathrm{t}_{\text {tabel }}\right)$.
Hal ini kemungkinan terjadi karena rasa yang dihasilkan dari keju slice dan batang tidak telalu berbeda dikarenakan juga berasal dari satu produk atau di produksi oleh satu perusahaan.

\section{KESIMPULAN}

Dari hasil analisis uji t $(\alpha=5 \%)$ keju cheddar batang dan keju cheddar slice tidak memberikan perbedaan yang nyata $(\mathrm{P}>0,05)$ terhadap TPC dan kapang khamir masing-masing keju cheddar masing - masing keju tidak memberikan perbedaan yang nyata $(\mathrm{P}>0,05)$ terhadap $\mathrm{pH}$ dan $\mathrm{a}_{\mathrm{w}}$ pada masing-masing keju cheddar. Dari hasil pengamatan uji organoleptik pada warna keju terlihat bahwa para panelis sangat menyukai pada keju batang. Penilaian pada keju batang lebih tinggi dengan rata rata nilai yaitu 4 dibandingkan dengan keju cheddar yang berbentuk slice yang memiliki rata rata nilai yaitu 3,7 . begitupun pada penilaian tekstur dan rasa, pada keju cheddar yang berbentuk batang memiliki

\section{DAFTAR PUSTAKA}

Badan Standarisasi Nasional. 2008. Metode Pengujian Cemaran Mikroba Dalam Daging, Telur dan Susu, Serta Hasil Olahannya. Standar Nasional Indonesia. Badan Standarisasi Nasional. (SNI 2897:2008).

Buck, R. P,.et al. 2002. Measurement of pH.Definition, Standart and Prosedur (IUPAC Recommendation 2002). Journal international union of pure and applied chemistry.pureappl.chem., vol 74, No. 11, pp. 2169 2200,2002.

Saha, A., Mandal, P., dasgubta, S., Saha, D. 2088. Influence of culture Media and Envrionmental Factor on mycelia Growth and sporulation of Lasiopdiplodiatheobromae (Pat.) Griffon and maubl.Journal of envriomental Biology, 29(3):407-410.

Varga László. 2007. Microbiological quality of commercial dairy products. Communicating Current Research and Educational Topics and Trends in Applied Microbiology.Department of Dairy Science.Institute of Food Science.Faculty of Agricultural and Food Sciences. University of West Hungary, 15-17 Lucsony Street, 9200 Mosonmagyaróvár, Hungary.Formatex.

Dardanella Derry. 2007. Pengaruh Jenis Kemasan dan Kondisi Penyimpanan Terhadap Mutu Produk Keju Cheddar Selama Penyimpanan.Skrpsi. Departemen Teknologi Industri Pertanian. Fakultas Teknologi Pertanian. Institut Pertanian Bogor. Bogor.

Zulidar Juliana. 2011. Penentuan Kadar Air Pada Mie Instan di PT Indofood CBP Sukses Mamur Tbk Medan. Tugas Akhir. Program Studi Diploma III Analis Farmasi dan Makanan. Fakultas Farmasi. Universitas Sumatera Utara. Medan. 